\title{
Isolation and Characterization of Coumarin Isolated from Endophyte, Alternaria Species - 1 of Crotalaria pallida and Its Apoptotic Action on HeLa Cancer Cell Line
}

\author{
Umashankar $\mathbf{T}^{1}$, Govindappa $\mathbf{M}^{1 *}$, Yarappa Lakshmikantha $\mathbf{R}^{2}$, Padmalatha Rai $\mathbf{S}^{3}$ and Channabasava ${ }^{1}$ \\ ${ }^{1}$ Endophytic Natural Product Laboratory, Department of Biotechnology, Shridevi Institute of Engineering and Technology, Sira Road, Tumkur-572 106, Karnataka, India \\ ${ }^{2}$ Department of P.G. Studies and Research in Biotechnology and Bioinformatics, Kuvempu University, JnanaSahyadri, Shankaraghatta, Shimoga, Karnataka -577 451, India
} ${ }^{3}$ Department of Biotechnology, School of Life Sciences, Planetorium Complex, Manipal University, Manipal-576 104, Udupi Dist, Karnataka State, India

\begin{abstract}
Endophyte, Alternaria species-1 isolated from leaf part of Crotalaria pallida was selected in isolation, identification and purification of coumarin. HPLC, UV-spectrophotometry, FTIR, NMR and XRD studies were carried out on characterization of endophytic fungal coumarin. In vitro apoptotic activity was carried out against HeLa cervical cancer cell lines. The results of MTT studies, acridine staining activity revealed the coumarin as an effective in inducing apoptotic activity in HeLa cells. The coumarin significantly inhibited the proliferation of HeLa cells and it's a concentration and time dependent manner. Significant elevation of caspase 3 and 9 and activity was observed in coumarin treated HeLa cells but no elevation or activity of caspase $7,8,10$ was not observed. Coumarin has shown $0.156 \mu \mathrm{g} / \mathrm{ml}$ of significant $\mathrm{IC}_{50}$ value against viable of HeLa cell lines. Thus, coumarin exerts apoptotic activity by caspase dependent apoptosis by enhancing the caspase 3 and 9 and it degraded the DNA (avoided the further replication). This is the first report in internationally that coumarin isolated from endophyte, Alternaria species-1, purified and characterized and its role was identified in apoptotic activity.
\end{abstract}

Keywords: Endophyte; Alternaria sp; Coumarin; HPLC; XRD; FTIR; Apoptosis

\section{Introduction}

Cancer is a generic term refers to the large group of diseases characterized by abnormal growth of cells by rapidly beyond their usual boundaries, invading to other parts of the body organs leading to the formation of malignant tumors and neoplasmas. Cancer causes 1 in 8 deaths and rapidly becoming pandemic all over the globe (WHO, 2015). There were around 14.1 million new cancer cases, 8.2 million cancer deaths and 32.6 million are living with cancer (IARC, 2012). This scenario of cancer has made focused on searching of new effective and economical both in usage and production of therapeutic agents. The cancer treatment is prolonged one, it is necessary to reinvestigate the therapeutics of short duration, less side effects, and economical. In this context natural products are considered to be the choice as apoptotic agents.

Coumarins are the benzopyrone compounds belong to flavonoid groups of secondary metabolites of plants. Presently there are more than 1300 coumarins have been identified in plants, bacteria, and fungi [1-3]. Coumarins have their specific fingerprints as antiviral [4], antimicrobial [5], antioxidant, anti-inflammatory [6,7], antiadipogenic [8], cytotoxic [9], apoptosis [10], antiprolilferative [11], antitubercular [12] and cytotoxicity [13] agent(s). Due to these wide range of pharmacological values, coumarins and its derivatives has got more importance in synthesis and production.

Crotalaria is one of the largest genera in tropical Africa. The genus includes 690 species that are mainly situated in Africa and Madagascar [14]. Species have also been found in India, United States of America (USA) and China. Crotalaria pallida Aiton (Fabaceae) is an erect shrub, annual or short-lived perennial herb of $1.5 \mathrm{~m}$ or more tall. The plant has been used as traditional medicine; its roots have been used to treat swelling of the joints and its leaves as vermifuge [15]. Coumarins were having been reported from different species of Crotalaria [16,17]. In this urge, the effective isolation of coumarins by the endophytes of Crotalaria pallida was felt worthy. Endophytes are any ubiquitous organisms, bacteria or fungi, occurring within plant tissues, distinct from the epiphytes that live on plant surfaces [18]. They inherit the characteristics of host plants in secreting the secondary metabolites [19-21]. These inheritance properties of endophytes are beneficial industrially in the production of important secondary metabolites.

The present study was aimed on, isolation and identification of endophytes of Crotalaria pallida, purification and characterization of endophytic coumarin by HPLC, UV spectra, XRD, FTIR and NMR, in vitro apoptotic activities on HeLa cell lines by MTT assay, acridine orange staining, analysis of caspase-3, 7, 8, 9 and 10 activity.

\section{Materials and Method}

\section{Collection and mass production of leaf endophyte, Alternatia species-1}

Collected the leaf endophyte, Alternaria species-1 from stock culture unit of Department of Biotechnology, Shridevi Institute of Engineering \& Technology, Tumkur, India were mass cultured on PDB broth for large scale cultivation which was then incubated at room temperature $26 \pm 2^{\circ} \mathrm{C}$ for 8 days.

*Corresponding author: Govindappa M, Endophytic Natural Product Laboratory, Department of Biotechnology, Shridevi Institute of Engineering and Technology, Sira Road, Tumkur-572 106, Karnataka, India, Tel: +91-7203238327; Fax: +91816-2212628; E-mail: dravidateja07@gmail.com, endophytessiet@gmail.com

Received November 17, 2015; Accepted December 08, 2015; Published December 10, 2015

Citation: Umashankar T, Govindappa M, Yarappa Lakshmikantha R, Padmalatha Rai S, Channabasava. (2015) Isolation and Characterization of Coumarin Isolated from Endophyte, Alternaria Species -1 of Crotalaria pallida and Its Apoptotic Action on HeLa Cancer Cell Line. Metabolomics 5: 158. doi:10.4172/2153-0769.1000158

Copyright: (c) 2015 Umashankar T, et al. This is an open-access article distributed under the terms of the Creative Commons Attribution License, which permits unrestricted use, distribution, and reproduction in any medium, provided the original author and source are credited. 
Citation: Umashankar T, Govindappa M, Yarappa Lakshmikantha R, Padmalatha Rai S, Channabasava. (2015) Isolation and Characterization of Coumarin Isolated from Endophyte, Alternaria Species -1 of Crotalaria pallida and Its Apoptotic Action on HeLa Cancer Cell Line. Metabolomics 5: 158. doi:10.4172/2153-0769.1000158

Page 2 of 8

\section{Microwave-assisted extraction (MAE)}

After incubation, the fungal mycelium mat was taken for extraction using ethanol. Based on the earlier report of Umashankar et al. [22], Microwave Assisted Extraction (MAE) method was used, the endophytic fungal mat mixed with ethanol was kept for extraction in microwave method at 2 cycles of 5 minutes each at $100^{\circ} \mathrm{C}$

\section{Identification of coumarins in the extracts}

Extract containing coumarins was confirmed by the confirmation tests [23]. Extracts containing phenolic compound were confirmed by the confirmation tests [24].

Test 1: $3 \mathrm{ml}$ of ethanol extract was evaporated to dryness in a vessel and the residue was dissolved in hot distilled water. It was then cooled and divided into two test portions, one was reference, second was the test. To the second test tube added $0.5 \mathrm{ml}$ of $10 \%$ ammonium hydroxide. The occurrence of intense fluorescence indicates the presence of coumarins and derivatives [23].

Test 2: To the concentrated alcoholic extract, added few drop of alcohol $\mathrm{FeCl}_{3}$ solution deep green colour formed which turned to yellow on addition of conc. $\mathrm{HNO}_{3}$ indicates the presence of coumarins.

Test 3: The alcohol extract of drug was mixed with $1 \mathrm{~N} \mathrm{NaOH}$ solution (one $\mathrm{ml}$ each). Development of blue green fluorescence indicates presence of coumarins.

\section{Test 4}

Detection of phenols: In beakers, $5 \mathrm{ml}$ of each previous filtered extract were taken and $1 \mathrm{ml}$ of $\mathrm{FeCl}_{3}(1 \%)$ and $1 \mathrm{ml} \mathrm{K}_{3}\left(\mathrm{Fe}(\mathrm{CN})_{6}\right)$ (1\%) were added. The appearance of fresh radish blue color indicated the presence of polyphenols [24]

\section{Isolation, purification of coumarin from Alternaria species-1} from high performance liquid chromatography (HPLC)

Identification, isolation and purification of coumarin were done using Alternaria species-1ethanol extract based on our earlier report [13].

The obtained chromatograms were compared with standards based on retention at $18.7 \mathrm{~min}$ is p-coumaric acid, $30.227 \mathrm{~min}$ is 2- hydroxyl cinnamic acid and $31.231 \mathrm{~min}$ is coumarin.

\section{UV-Visible spectrophotometry}

The coumarin absorption was carried out on a UV spectrophotometer at $305 \mathrm{~nm}$ in quartz cell. The coumarin was well known for their absorbance in the UV region of the spectra because of the mesomeric effect of the double bonds, and their phenolic cycle. The polyphenols are detectable, then at low concentration (1-10 l M).

\section{Fourier transform infrared spectroscopy (FTIR)}

The powder material and Alternaria species-1 mycelia mass was ground with a specially purified potassium bromide in a mortar and pestle. The ground mixture was then pressed in a mechanical press to form a translucent pellet. The infrared spectra of the materials were recorded using Agilent (Cary-630) Fourier transform spectrophotometer in the range of $400-4000 \mathrm{~cm}^{-1}$.

\section{$\mathrm{X}$-ray diffraction (XRD) studies}

The synthesized sample is gently grounded in an agar mortar and pestle. The fine powder is packed into a sample holder having a diameter of $1 \mathrm{~cm}$ and depth of $3 \mathrm{~mm}$. The surface of the packed sample is smoothed with a flat glass and then powder X-ray diffraction spectra of the samples are recorded on X'pert Pro X-ray diffractometer. The powder XRD involves the use of the collimated beam of X-rays; with wave lengths $\mathrm{Cu} \mathrm{Ka}$ radiation of wavelength in the range 0.5 to $2 \AA$, incident on a specimen, which is diffracted by the crystalline phase in the specimen. The identification of the phase(s) of the as sample was carried out by $\mathrm{x}$-ray powder diffraction (PANalytical X'pert X-ray powder diffractometer) using $\mathrm{Cu}-\mathrm{Ka}$ radiation at $\lambda=1.5418 \AA$. A scan step of $1 \mathrm{~s}$ and a step size of 0.1 (in $2 \theta$ ) were applied to record the patterns in the range of 5 to $70^{\circ}(2 \theta)$.

The Powder XRD pattern has been used to determine the symmetry of the crystallographic unit cell of the coumarin.

\section{C-13 NMR}

The solid coumarin was tested by NMR. The NMR spectrum of the crystalline coumarin was done in order to be compared to other spectra. The NMR tests were recorded at $300 \mathrm{MHz}$ on a Brucker spectrometer. Chemical shifts are expressed in part per million.

\section{In vitro apoptosis activity on HeLa cell lines}

HeLa (cervical cancer) cell lines was obtained from NCCS (National Centre for Cell Science), Pune. The HeLa cells were cultured in DMEM $10 \%$ FBS complete medium. The medium was supplemented with $10 \%$ heat inactivated fetal bovine serum and antibiotics. The cell lines were maintained at $37^{\circ} \mathrm{C}$ in a $5 \% \mathrm{CO}_{2}$ incubator and the media were changed frequently.

\section{MTT assay}

This is a colorimetric assay that measures the reduction of yellow 3-(4,5-dimethythiazol-2-yl)-2,5-diphenyl tetrazolium bromide (MTT) by mitochondrial succinate dehydrogenase. The MTT enters the cells and passes into the mitochondria where it is reduced to an insoluble, coloured (dark purple) formazan product. The cells are then solubilised with an organic solvent and the released, solubilised formazan reagent is measured spectrophotometrically. Since reduction of MTT can only occur in metabolically active cells, the level of activity is a measure of the viability of the cells. Experimental designs were done at 24 and $48 \mathrm{~h}$ based on procedure of Umashankar et al. [13].

\section{Detection of apoptosis by acridine orange staining}

Detection of apoptosis in HeLa cell lines is characterized by the double staining with acridine orange and ethidium bromide [25]. Live cells are observed by bright dots and dead cells by orange to brown colour. $2 \times 10^{4}$ cells per well were seeded in 96 well plate and treated for $48 \mathrm{~h}$. After incubation, the plates were centrifuged. $10 \mu \mathrm{l} \mathrm{of} 1 \mathrm{mg} /$ $\mathrm{ml}$ Acridine orange and Ethidium bromide mixture was added to each well. Nuclei were visualized and photographed under the fluorescent microscope. The differentiation in the staining of live and dead cells was observed with these two stains. Acridine orange stains both live and dead cells. The ethidium bromide stains only the dead cells by became organization due to intercalate DNA of cells with lost or degraded DNA of cell integrity.

\section{Determination of caspases activities}

The cells were harvested and washed in PBS at $4^{\circ} \mathrm{C}$ after incubation. Using caspase apoptosis kit, the caspases 3, 7, 8, 9 and 10 enzymes activities were analyzed and quantified [26,27] in coumarin treated HeLa cell line. All measurements were performed 3 times, and changes 
Citation: Umashankar T, Govindappa M, Yarappa Lakshmikantha R, Padmalatha Rai S, Channabasava. (2015) Isolation and Characterization of Coumarin Isolated from Endophyte, Alternaria Species -1 of Crotalaria pallida and Its Apoptotic Action on HeLa Cancer Cell Line. Metabolomics 5: 158. doi:10.4172/2153-0769.1000158

Page 3 of 8

in absorbance of each caspases were measured at $405 \mathrm{~nm}$ using an ELISA reader.

Ten $\mu \mathrm{g} / \mathrm{ml}$ of Alternaria species- 1 coumarin treated the HeLa cells to induce apoptosis, cells treated with DMSO and phosphate buffered saline ( $\mathrm{pH}$ 7.2) were used as control, standard drug 5-fluorouracil $(0.26 \mu \mathrm{g})$ was used as positive control. After treatment, the cells were incubated for $48 \mathrm{~h}$. After incubation, the cells were collected and suspended with cell lysis buffer, cells were incubated on ice for $10 \mathrm{~min}$ and centrifuged at 10,000 rpm for $5 \mathrm{~min}$ and supernatant obtained was treated with $4 \mathrm{ml}$ of $4 \mathrm{mM}$ pNA-conjugated substrates (DEVD-pNA) and incubated for $3.5 \mathrm{~h}$ at $37^{\circ} \mathrm{C}$. The released amount of pNA from each treatment was measured at $405 \mathrm{~nm}$ using ELISA microplates reader. Based treated to untreated cells the absorbance of the relative caspase activity was calculated.

To study the inhibitory action of caspase-3, 7, 8, 9 and 10 in the extract, the sample was pre-incubated with inhibitor in cell lysate samples at room temperature $\left(26 \pm 2^{\circ} \mathrm{C}\right)$ for $10 \mathrm{~min}$ before adding caspases $3,7,8,9$ and 10 substrate solution separately.

\section{Results}

The endophyte, Alternaria species-1 have shown the presence of coumarin in all the tested methods and also confirms the presence of polyphenols, it indicates coumarin presence (Table 1). These methods are commonly using to study coumarin presence in the extract.

\section{Identification of coumarins in the extracts by HPLC}

When we compared with standard coumarins, the results confirmed the presence of two coumarins ( $\mathrm{p}$-coumaric acid and coumarin) at high per cent in ethanol extracts of Alternaria species-1 in HPLC method (Table 2). Figure 1 depicts the standard coumarins in HPLC. The ethanol extract of leaf part of Crotalaria pallida has shown three different types of coumarins (Figure 2). The ethanol extract of fungal endophyte, Alternaria species-1 yielded only two coumarins viz., p-coumaric acid and coumarin, they were identified based on their retention time and compared with standard in HPLC (Figure 3 and 4). Purified coumarin based on retention time (31.514) and obtained single peak in HPLC after collecting the bulk quantity (Figure 5). The coumarin was isolated and purified from Alternaria species-1 using HPLC based on retention time (31.514) and done the experiment repeatedly to collect the purified coumarin at large quantity and run the same sample in the HPLC to know its purity and to obtain pure coumarin for in vitro apoptosis activity. The purified coumarin was characterized by other specific analytical methods and parameters such as UV-Vis, XRD, FTIR and NMR studies. The results of these studies were very significant for purity and confirmed. These methods were used to characterize and confirm the coumarins isolated different sources [28-30].

Using diode array detector plotted the chromatographic/ spectrometric data images. It was used to facilitate HPLC method to optimize and validity for detection conditions in off-line also (Figure 9). Based on linearity, sensitivity, precision, repeatability, and accuracy the method was validated. The method was used to determine seven phenolic compounds include p-coumaric acid [31,32]. To improve the quantitative analysis method established the iso-plot method and it is effective also. Using C18 column with gradient elution of phosphoric acid aqueous solution $(0.05 \%, \mathrm{v} / \mathrm{v})$ and acetonitrile the chromatographic separation was done, and adopted detection of isolated $\mathrm{p}$-coumaric acid using wave lengths switch programme and optimized with iso-plot. Isolation and purification of coumarins were carried out by the repeated performance and collection of specific

\begin{tabular}{|c|c|}
\hline Phytochemicals & Alternaria species-1 (Leaf) \\
\hline Phenols & +++ \\
\hline Coumarin test 1 & +++ \\
\hline Coumarin test 2 & +++ \\
\hline Coumarin test 3 & +++ \\
\hline
\end{tabular}

"Repeated the each experiment thrice, +=Presence, ++=Medium, +++=More and -=Absence

Table 1: Identification of coumarins and phenol in leaf endophyte, Alternaria species-1.

\begin{tabular}{|c|c|c|}
\hline Coumarins & Leaf extract & $\begin{array}{c}\text { Alternaria species-1 } \\
\text { (Leaf) }\end{array}$ \\
\hline p-Coumaric acid & + & + \\
\hline 2-Hydroxy coumaric acid & - & - \\
\hline Coumarin & + & + \\
\hline
\end{tabular}

Note: +: presence, -: absence

Table 2: Presence of two different coumarins in plant extract and Alternaria species-1.

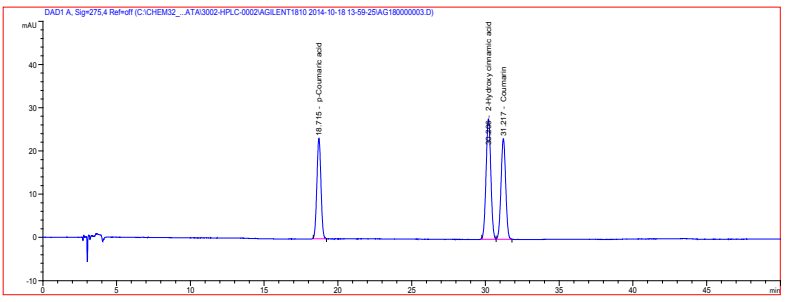

Figure 1: Standard chromatogram of all the three coumarins in HPLC.

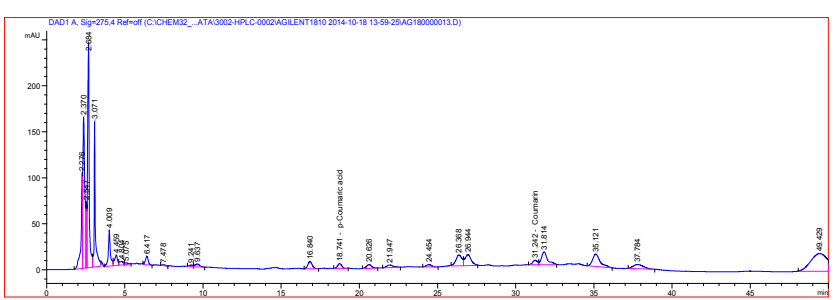

Figure 2: HPLC chromatogram of leaf extract of Crotalaria pallida.



Figure 3: HPLC chromatogram of leaf Alternaria species-1 ethanol extract.

coumarins at their respective retention time. The purified coumarins were again characterized by other specific analytical methods and parameters. The purity of coumarin was confirmed by the isoplot, 3D plot, spectral studies, peak purity information, HPLC RT and 3D plot of RT studies. The results of these studies were very significant. Temperature $(\mathrm{T})$ on one axis, pressure $(\mathrm{p})$ on a second axis, and specific 
Citation: Umashankar T, Govindappa M, Yarappa Lakshmikantha R, Padmalatha Rai S, Channabasava. (2015) Isolation and Characterization of Coumarin Isolated from Endophyte, Alternaria Species -1 of Crotalaria pallida and Its Apoptotic Action on HeLa Cancer Cell Line. Metabolomics 5: 158. doi:10.4172/2153-0769.1000158

volume (v) on a third was done to coumarin using 3D plot graph. Based these studies coumarin was isolated and purified and again subjected HPLC to know the purity. Phenolic compounds absorb ultraviolet region strongly and detection and quantification the spectra was used. Detected the phenolic compounds by studying absorbance at $280 \mathrm{~nm}$ from the eluent after separation with selecting mobile and stationary phases. Our results confirmed by the results of Hosler et al. [24].

The coumarin absorption was carried out on a UV spectrophotometer at $305 \mathrm{~nm}$ in quartz cell. The coumarin was well known for their absorbance in the UV region of the spectra because of the mesomeric effect of the double bonds, and their phenolic cycle. In this range, studied absorption showed four absorption bands at $241 \mathrm{~nm}$, $297 \mathrm{~nm}, 277 \mathrm{~nm}$ and $307 \mathrm{~nm}$ for the coumarin standard and coumarin from the extract of Alternaria species-1 (Figure 6 and 7).

\section{FTIR}

The IR spectrum of coumarin shows lactone carbonyl at $1715 \mathrm{~cm}^{-1}$, $v \mathrm{C}=\mathrm{C}$ at $1608 \mathrm{~cm}^{-1}, 1450 \mathrm{~cm}^{-1}$ and $v \mathrm{C}-\mathrm{O}-\mathrm{C}$ at $1254 \mathrm{~cm}^{-1}$. Infrared spectroscopy involves the absorption of electromagnetic radiation in the infrared region of the spectrum which results in changes in the vibrational energy of molecules. Usually all molecules have vibrations in the form of stretching, bending, etc., the absorbed energy will be utilised in changing the energy levels associated with them [33]. The IR spectrum of coumarin shows a sharp band at $3381 \mathrm{~cm}^{-1}$ associated to the stretching -OH vibration. The band at $2963 \mathrm{~cm}^{-1}$ associated with the aromatic $\mathrm{CH}$-stretching. The band present at 1715 reflecting the $\mathrm{CO}$-stretching of carbonyl group of $\mathrm{COOH}$ (Figure 8 and 9) and it was compared with standard and the purity of the compound is similar to standard coumarin. The shows the FTIR spectrum of coumarin laser dye and compared with chemical formula of this dye. There were more than one peak obtained in region of the $\mathrm{C}-\mathrm{H}$ bending vibrations out of plane (900-600) $\mathrm{cm}^{-1}$ can support the presence of an aromatic structure. In region (1200-1000) $\mathrm{cm}^{-1}$, there is a peak at $1028.09 \mathrm{~cm}^{-1}$ refers to C-H bending vibrations in of planes. The benzene rings very clear which is supportive to the peak at $1489.10 \mathrm{~cm}^{-1}$ that acts the $\mathrm{C}=\mathrm{C}$ stretching (1400-1600) $\mathrm{cm}^{-1}$ of the benzene ring and a peak at $3061.13 \mathrm{~cm}^{-1}$ for C-H stretching (3000-3100) $\mathrm{cm}^{-1}$.

\section{XRD}

The powder XRD pattern of the coumarin corresponds to

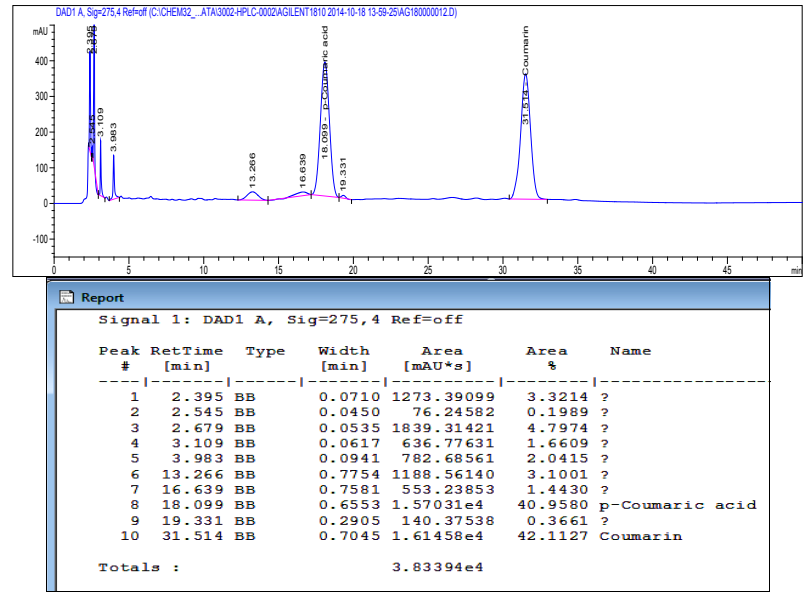

Figure 4: Separation of p-coumaric acid and coumarin from the crude extract and its area summary.

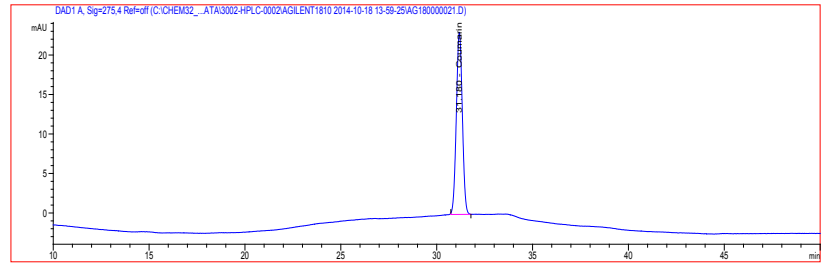

Figure 5: Purified coumarin from Alternaria species-1 showing 31.130 retention time.

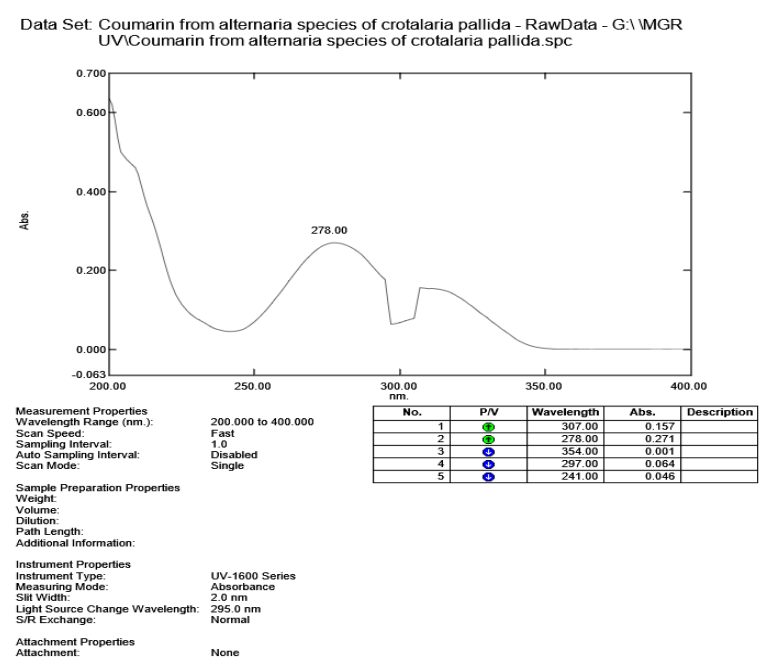

Figure 6: UV-visible spectra: coumarin from the extract of Alternaria species-1.

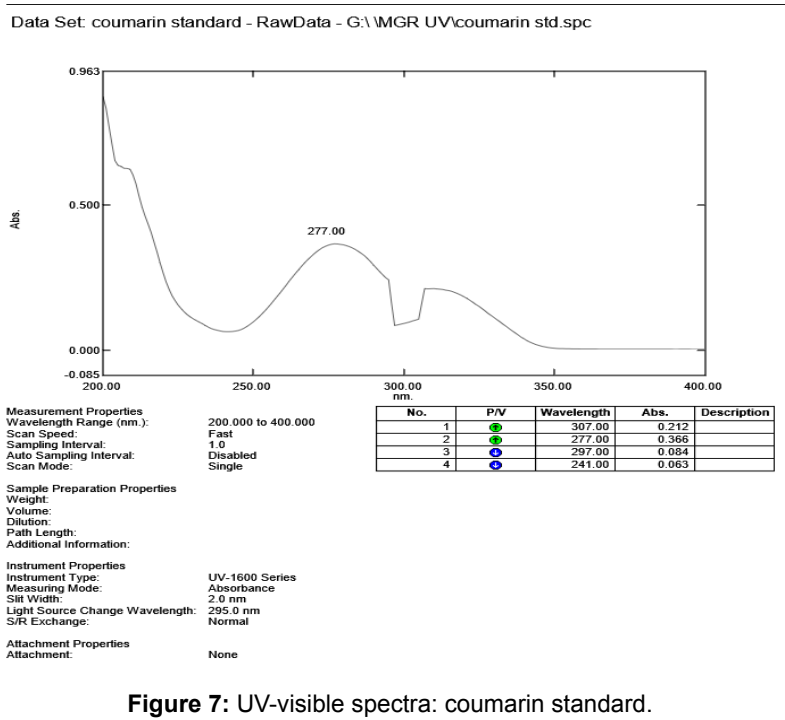

orthorhombic phase with space group $\mathrm{Pca}^{\mathrm{z}}(\mathrm{Z}=4)$ (Figure 10).

A typical analysis of a ${ }^{13} \mathrm{C}$ NMR spectrum consists of matching expected chemical shifts to the expected moieties. The chemical shifts were matched with the existed earlier reports. For coumarin, chemical shifts 103.326, 109.818 and 103.322 were characteristic (Figure 6). The 
Citation: Umashankar T, Govindappa M, Yarappa Lakshmikantha R, Padmalatha Rai S, Channabasava. (2015) Isolation and Characterization of Coumarin Isolated from Endophyte, Alternaria Species -1 of Crotalaria pallida and Its Apoptotic Action on HeLa Cancer Cell Line. Metabolomics 5: 158. doi:10.4172/2153-0769.1000158

Page 5 of 8

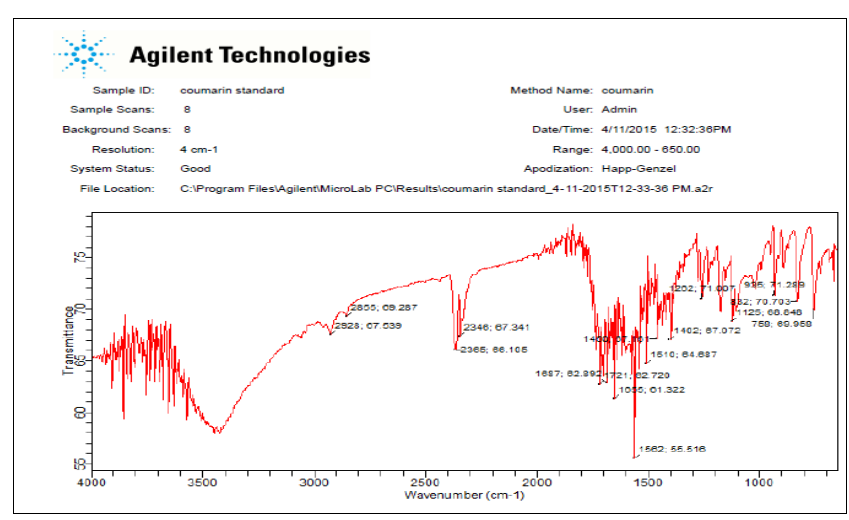

Figure 8: FTIR spectra of standard coumarin.

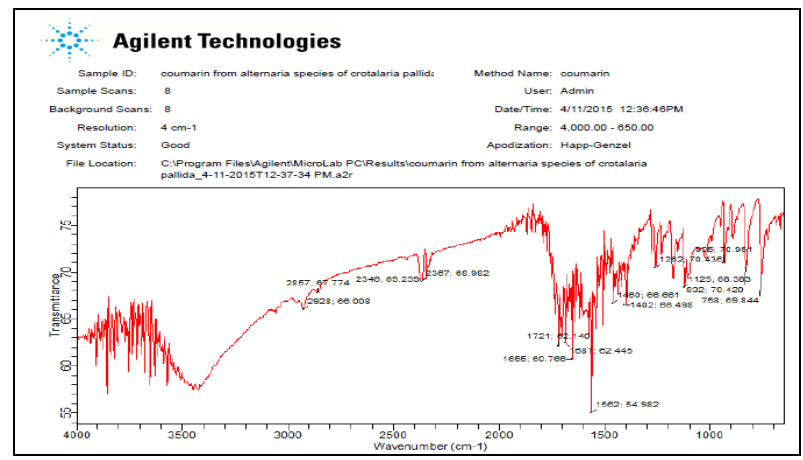

Figure 9: FTIR spectra of purified coumarin from the extract of Altemaria species-1.

results are compared with IR spectra of standard coumarin (Figure 11).

\section{In vitro apoptotic activity on HeLa cell lines}

In vitro apoptotic activity on HeLa cell lines shows that, the endophytic fungal coumarin from Alternaria species-1 has remarkable apoptotic activity on cancer cell lines. MTT assay showed that the decrease in the cell viability after 24 and $48 \mathrm{~h}$. Apoptotic activity of endophytic fungal coumarin was demonstrated by its inhibition of proliferation of HeLa (cervical cancer) cells in a time and dosedependent manner. $0.156 \mu \mathrm{g} / \mathrm{ml}$ of significant IC $_{50}$ value was noticed (Figure 11 and 12) (Table 3).

\section{Acridine orange and ethidium bromide staining}

Detection of apoptosis in HeLa cell lines stained with acridine orange and ethidium bromide treated by coumarin has given significant results. The live cells were appeared as bright green spots and dead cells are as orange to brown. Control treated cells showed most of the live cells and there are more dead cells at $48 \mathrm{~h}$ of treatment than the cells treated for $24 \mathrm{~h}$. Staining with orange or brown is due to the ethidium bromide, which acts as intercalate agent with apoptic cell DNA (Figure 13 and 14).

Caspases are known to be involved in pivotal regulator of cellular apoptosis [33]. We have identified the effect or role of coumarin on activation of caspases $3,7,8,9$ and 10 by calorimetric method. The p-coumaric acid effectively induced the activity of caspases 3 and 9 in HeLa cells and no effect was observed in caspases 7, 8 and 10 activities.

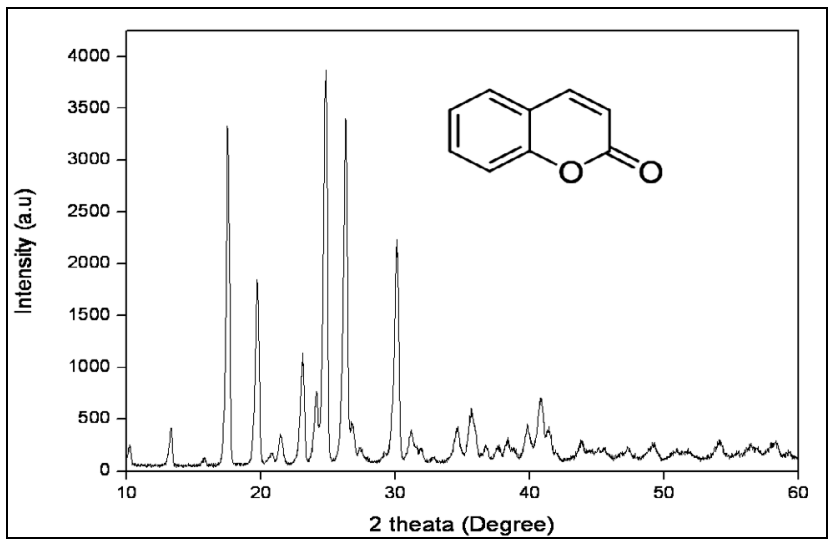

Figure 10: XRD patterns of the coumarin corresponds to orthorhombic phase.



Figure 11: C-NMR pattern of the coumarin from the extract of Alternaria species-1.

From the results, conclude that the coumarin isolated from Alternaria species- 1 treatment enhanced the cell death of HeLa cancer cell line by activating caspases enzymes in intrinsic pathways (Figure 15).

Alternaira species-1 coumarin induced apoptosis in HeLa cells was associated with typical apoptosis by nuclear DNA degradation and induction of caspase- 3 and 9 activity.

\section{Discussion}

Production of secondary metabolites from endophytes is a wide area. It depends on the host plant, endophytic fungi, laboratory conditions and other optimization parameters. Based upon our earlier in vitro biological and HPLC screening studies [13,22], Alternaria sp. have been selected for isolation and purification of coumarin and its cytotoxicity on HeLa cell lines. Investigations of Taxol, the first apoptotic agent recovered by an endophytic fungi Taxomyces andreanae of Taxus brevifolia [34] and other apoptotic drugs, Paclitaxel from Alternaria sp. of Taxus cuspidata, Ginkgo biloba and Taxus chinensis [35-37], Podophyllotoxin from Alternaria sp. of Sinopodophyllum hexandrum, Sabina vulgaris and Sinopodophyllum hexandrum [3840] strengthens this apoptotic study in relation to endophytes and the selected Alternaria species.

The detailed analytical characterization studies of coumarin confirmed its presence in endophyte Alternaria species-1 of Crotalaria 
Citation: Umashankar T, Govindappa M, Yarappa Lakshmikantha R, Padmalatha Rai S, Channabasava. (2015) Isolation and Characterization of Coumarin Isolated from Endophyte, Alternaria Species -1 of Crotalaria pallida and Its Apoptotic Action on HeLa Cancer Cell Line. Metabolomics 5: 158. doi:10.4172/2153-0769.1000158



Figure 12: In vitro apoptotic activity of endophytic coumarin from Alternaria species-1 on HeLa cancer cell lines.

\begin{tabular}{|c|c|c|c|c|}
\hline $\begin{array}{c}\text { Drug } \\
\text { concentration } \\
(\mu \mathrm{g})\end{array}$ & $\%$ of viability & & $\begin{array}{c}\% \text { of cell } \\
\text { death }\end{array}$ & \\
\hline & $24 h$ & $48 \mathrm{~h}$ & $24 \mathrm{~h}$ & $48 \mathrm{~h}$ \\
\hline 0.078 & $88.664 \pm 0.01$ & $87.38 \pm 0.02$ & $11.34 \pm 0.02$ & $12.62 \pm 0.01$ \\
\hline 0.156 & $48.36 \pm 0.02$ & $39.9 \pm 0.02$ & $51.64 \pm 0.02$ & $60.1 \pm 0.01$ \\
\hline 0.312 & $17.784 \pm 0.01$ & $14.03 \pm 0.01$ & $82.21 \pm 0.01$ & $85.7 \pm 0.02$ \\
\hline 0.625 & $8.684 \pm 0.01$ & $9.303 \pm 0.01$ & $91.31 \pm 0.02$ & $90.97 \pm 0.02$ \\
\hline 1.25 & $1.352 \pm 0.01$ & $1.143 \pm 0.02$ & $98.64 \pm 0.01$ & $98.87 \pm 0.01$ \\
\hline 2.5 & $0.416 \pm 0.02$ & $0.467 \pm 0.01$ & $99.58 \pm 0.03$ & $99.53 \pm 0.03$ \\
\hline 5 & $1.456 \pm 0.03$ & $1.61 \pm 0.03$ & $98.54 \pm 0.02$ & $98.39 \pm 0.02$ \\
\hline Vehicle control & $97.8 \pm 0.02$ & $97.5 \pm 0.02$ & $2.2 \pm 0.0$ & $2.5 \pm 0.0$ \\
\hline Doxorubicin & $10.13 \pm 0.1$ & $07.0 \pm 0.1$ & $89.87 \pm 0.2$ & $93 \pm 0.1$ \\
\hline $\mathrm{IC}_{50}$ & \multicolumn{4}{|c|}{$0.156 \mu \mathrm{g}$} \\
\hline
\end{tabular}

Table 3: In vitro apoptotic activity of endophytic coumarin from Alternaria species on HeLa cancer cell lines.

pallida. HPLC results were found similar with the results of standard coumarin. FTIR results of endophytic coumarin were confirmed by the earlier studies reported by Murthi et al. [41]. The XRD results were also significant and confirmed by the reports of Ramaswamy [42]. Similar works were carried out in characterization of coumarin in Justicia pectoralis leaf [43], Melilotus suaveolens [44]. A cytotoxic activity of endophytic coumarin of Alternaria species- 1 on cancerous HeLa cell lines was extensively significant having an $\mathrm{IC}_{50}$ value of $0.156 \mu \mathrm{g} / \mathrm{ml}$. MTT assay, acridine orange staining and caspase- 3 colorimetric studies reveals that, the cyotoxicity of endophytic coumarin on viable of $\mathrm{HeLa}$ cells is due to DNA degradation and induction of apoptic caspase-3 and 9 enzyme activity. Caspases trigger apoptosis through a well-orchestrated cascade $[45,46]$. Caspases are crucial mediators of programmed cell death (apoptosis). Among them caspase-3 is frequently associated
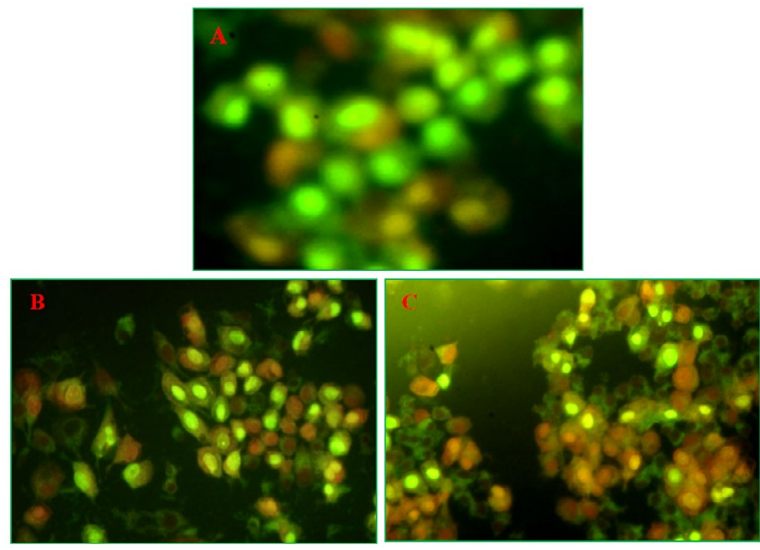

Figure 13: Detection of apoptosis in HeLa cell lines stained by acridine orange treated by endophytic coumarin, A) Control, B) HeLa cell lines after $24 \mathrm{~h}$ and C) HeLa cell lines after $48 \mathrm{~h}$

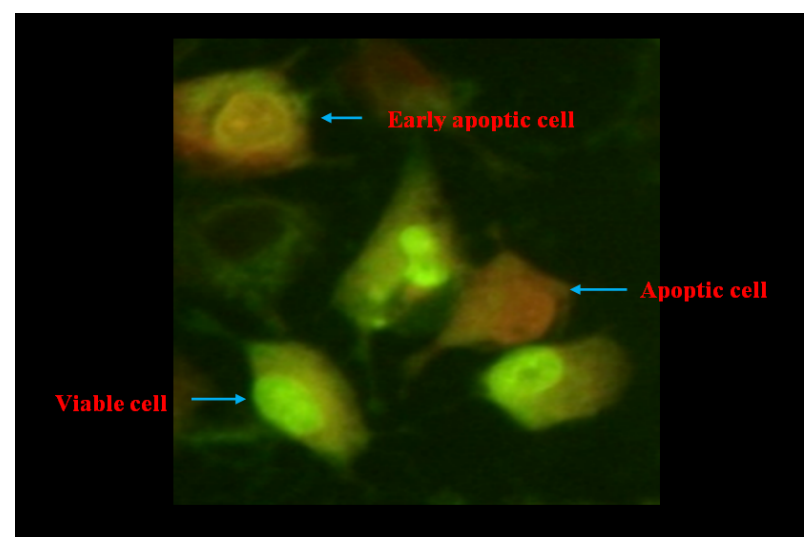

Figure 14: Detection of apoptosis HeLa cell lines.

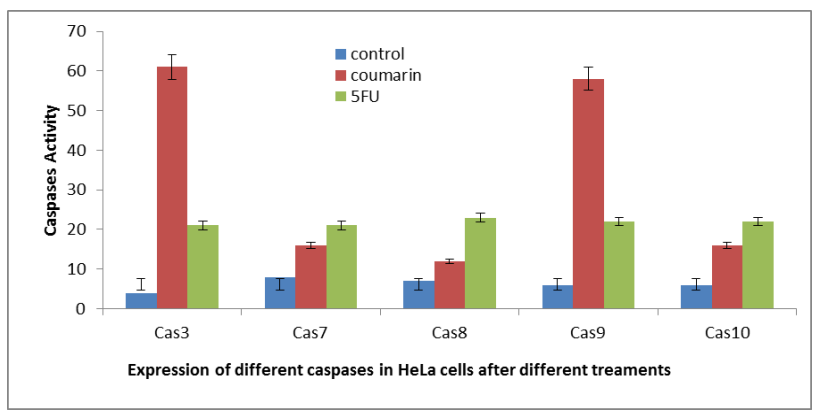

Figure 15: Changes in different caspase activity in HeLa cell line after treatment with Alternaria species-1 coumarin.

protease, catalyzing the target specific cleavage of many key cellular proteins [47]. Caspase -7 is executioner caspases, activates the intrinsic apoptotic pathways through cleavage of BID to induce efficient cell death, apoptotic cell development. Caspase-9 initiates apoptosis by cleaving and thereby activating executioner caspases, mitochondrial morphological changes, ROS production by cleaving and activating 
Citation: Umashankar T, Govindappa M, Yarappa Lakshmikantha R, Padmalatha Rai S, Channabasava. (2015) Isolation and Characterization of Coumarin Isolated from Endophyte, Alternaria Species -1 of Crotalaria pallida and Its Apoptotic Action on HeLa Cancer Cell Line. Metabolomics 5: 158. doi:10.4172/2153-0769.1000158

Page 7 of 8

BID into tBID [48]. Caspase-10 is initiate caspase in death receptor signaling [49].

The acridine orange fluoroscent study clearly reveals that the cytotoxicity on HeLa cells is due to cytostasis but not through cell necrosis. Apoptic activities of endophytic coumarin were rectified by the recent works carried out in HeLa cells with different apoptotic drugs and fungal secondary metabolites [50-52]. The natural coumarins induces apoptosis like cell death in HeLa cells mediated by the release of apoptosis inducing factor [53] but our source is different i.e. endophytic fungi. Interestingly, we also found caspase depended apoptosis from our experiment whereas, we found elevation of caspase- 3 activity. The coumarin induces morphological changes, G0/G1 arrest, DNA fragmentation and increased the sub-G1 group, affected the production of reactive oxygen species and $\mathrm{Ca}^{2+}$ concentration, depolarization of mitochondrial membrane potential, the anti-apoptotic proteins $\mathrm{Bcl}-2$ and $\mathrm{Bcl}-\mathrm{xL}$, and increased the expression of the pro-apoptotic protein Bax, decreased the mitochondrial membrane potential and promoted the release of cytochrome $c$ and the activation of caspase- 3 before leading to apoptosis in human cervical cancer cells (HeLa) [54]. Our endophytic fungal coumarin have shows some of the above results such as caspase-3 activity, toxicity and DNA fragmentation in HeLa cancer cells.

\section{Conclusion}

In conclusion, the endophytic coumarin was isolated, identified by the detailed UV-Vis, HPLC, FTIR, XRD, NMR studies. Apoptotic activity was confirmed by MTT assay, acridine orange staining and more activity of caspase 3 and 9. The mechanism of endophytic coumarin was assumed through DNA degradation and induction of caspase- 3 and 9 activities without any cell necrosis. Further, optimal studies are needed to investigate in vivo condition, in dose fixation and other etiological studies. This is the first report on identified the coumarin produce endophyte, Alternaria species-1, its characterization and apoptotic activity in nationally and internationally. The endophytic fungi can be used for production of apoptotic agent, coumarin.

\section{Acknowledgement}

We thank Dr. MR Hulinaykar, Managing Trustee, Sri Shridevi Charitable Trust (R.) and Dr. Nalini N, Principal, SIET, Tumkur, India for encouragement and suggestions during the research, Dr. KG Bhat, Taxonomist, Udupi, for his assistance in collection and identification of the plant. We thank the Spectroscopic unit of Indian Institute of Science, Bangalore, Karnataka, India, for their extended service in assisting the technical help during this research work.

\section{References}

1. http://www.who.int/mediacentre/factsheets/fs297/en/

2. http://www.iarc.fr/en/media-centre/iarcnews/index1.php?year=2012

3. Iranshahi M, Askari M, Sahebkar A, Litina DH (2009) Evaluation of antioxidant, anti-inflammatory and lipoxygenase inhibitory activities of the prenylated coumarin umbelliprenin. DARU 17: 99-103.

4. Newman RA, Chen W, Madden TL (1998) Pharmaceutical properties of related calanolide compounds with activity against human immunodeficiency virus. J Pharm Sci 87: 1077-1080.

5. Leon WN, Savadogo A, Simpore J, Dianou D, Traore AS (2012) In vitro Antimicrobial Activity of Some Phenolic Compounds (Coumarin and Quercetin) Against Gastroenteritis Bacterial Strains. Int J Microbiol Res 3: 183-187.

6. Witaicenis A, Seito LN, Di Stasi LC (2010) Intestinal antiinflammatory activity of esculetin and 4-methylesculetin in the trinitrobenzenesulphonic acid model of rat colitis. Chem Biol Interact 186: 211-218.

7. Kwon OS, Choi JS, Islam MN, Kim YS, Kim HP (2011) Inhibition of 5lipoxygenase and skin inflammation by the aerial parts of Artemisia capillaris and its constituents. Arch Pharm Res 34: 1561-1569.

8. Shin E, Choi KM, Yoo HS, Lee CK, Hwang BY, et al. (2010) Inhibitory effects of coumarins from the stem barks of Fraxinus rhynchophylla on adipocyte differentiation in 3T3-L1 cells. Biol Pharm Bull 33: 1610-1614.

9. Mahmoodi M, Aliabadi A, Emami S, Safavi M, Rajabalian S, et al. (2010) Synthesis and in-vitro cytotoxicity of poly-functionalized 4-(2-arylthiazol-4-yl)4H-chromenes. Arch Pharm 343: 411-416.

10. Luo KW, Sun JG, Chan JY, Yang L, Wu SH, et al. (2011) Anticancer effects of imperatorin isolated from Angelica dahurica: induction of apoptosis in HepG2 cells through both death-receptor and mitochondria-mediated pathways. Chemotherapy 57: 449-459.

11. Yun ES, Park SS, Shin HC, Choi YH, Kim WJ, et al. (2011) p38 MAPK activation is required for esculetin-induced inhibition of vascular smooth muscle cells proliferation. Toxicology in vitro 25: 1335-1342.

12. Chiang CC, Cheng MJ, Peng CF, Huang HY, Chen IS (2010) A novel dimeric coumarin analog and antimycobacterial constituents from Fatoua pilosa. Chem Biodivers 7: 1728-1736.

13. Umashankar T, Govindappa M, Ramachandra YL Chandrappa CP, Padmalatha Rai S, et al. (2015) Isolation, purification and in vitro cytotoxicity activities of coumarin isolated from endophytic fungi, Alternaria species of Crotalaria pallida. Indo Am J Pharm Res 5: 926-936.

14. Van Wyk BE, Moteetee AN, Tilney PM (2009) An evaluation of molecular and anatomical characters in the genus Crotalaria. S Afr J Bot 75: 410.

15. Jain SK, Borthakur SK (1980) Etnobotany of the Mikers of India. Econ Bot 34 264-272.

16. Bhakshu LM, Ratnam KV, Venkataraju RR (2008) Medicinal properties and antimicrobial activity of Crotalaria madurensis var. kurnoolica. Ethanobotanical Letters 12: 758-762.

17. Rao MS, Narukulla R (2007) A new trimethoxychalcone from Crotalaria ramosissima. Fitoterapia 78: 446-447.

18. Carroll GC (1986) The biology of endophytism in plants with particular reference to woody plants. Cambridge University Press, UK.

19. Kusari S, Hertweck C, Spiteller M (2012) Chemical ecology of endophytic fungi: origins of secondary metabolites. Chem Biol 19: 792-798

20. Sachin N, Manjunatha BL, Mohana Kumara P, Ravikanth, G, Shweta S, et al. (2013) Do endophytic fungi possess pathway genes for plant secondary metabolites? Curr. Sci 104: 178-182.

21. Heinig U, Scholz S, Jennewein $S$ (2013) Getting to the bottom of Taxo biosynthesis by fungi. Fungal Divers 60:161-170.

22. Umashankar T, Govindappa M, Ramachandra YL (2014) In vitro antioxidant and antimicrobial activity of partially purified coumarins from fungal endophytes of Crotalaria pallida. Int J Curr Microbiol App Sci 3: 58-72.

23. Jagessar RC, Cox $M$ (2010) Phytochemical screening of the $\mathrm{CHCl}_{3}$ and $\mathrm{CH}_{3} \mathrm{CH}_{2} \mathrm{OH}$ extract of stems, twigs, roots, and barks of Conocarpus erectus $\mathrm{L}$. Int J Acad Res 2: 36-45.

24. Farhan H, Rammal H, Hijazi A, Hamad H, Badran B (2012) Phytochemical screening and extraction of polyphenol from stems and leaves of a Lebanese Euphorbia macrolada schyzoceras Boiss. Ann Biol Res 3: 149-156.

25. Deborah R, Goldstein NB, Norris DA, Shellman YG (2005) A simple technique for quantifying apoptosis in 96 well plates. BMC Biotechnology 5: 12.

26. Irshad M, Mehdi SJ, Al-Fatlawi AA, Zafaryah Md, Ali A, et al. (2014) Phytochemical composition of Cassia fistula fruit extracts and its anticancer activity against human cancer cell lines. Journal of Biologically Active Products from Nature 4: 158-170.

27. Wang J, Lu ML, Dai HL, Zhang SP, Wang HX (2015) Esculetin, a courmarin derivative, exerts in vitro and in vivo antiproliferative activity against hepatocellular carcinoma by initiating a mitochondrial apoptosis pathway. Braz J Med Biol Res 48:245-253.

28. Sahoo J, Mekap SK , Kumar PS (2015) Synthesis, spectral characterization of some new 3-heteroaryl azo 4-hydroxy coumarin derivatives and their antimicrobial evaluation. J Taibah Univ Sci 9: 187-195.

29. Cannava C, Crupi V, Ficarra P, Guardo M, D. Majolino, et al. (2008) Physicochemical characterization of coumestrol/ $\beta$-cyclodextrins inclusion 
Citation: Umashankar T, Govindappa M, Yarappa Lakshmikantha R, Padmalatha Rai S, Channabasava. (2015) Isolation and Characterization of Coumarin Isolated from Endophyte, Alternaria Species -1 of Crotalaria pallida and Its Apoptotic Action on HeLa Cancer Cell Line. Metabolomics 5: 158. doi:10.4172/2153-0769.1000158

complexes by UV-vis and FTIR-ATR spectroscopies. Vibrat Spec 48: 172-178.

30. Zolfigol MA, Ayazi-Nasrabadi R, Baghery S (2015) Synthesis and characterization of two novel biological-based nano organo solid acids with urea moiety and their catalytic applications in the synthesis of 4,4'-(arylmethylene) bis(1H-pyrazol-5-ol), coumarin-3-carboxylic acid and cinnamic acid derivatives under mild and green conditions. RSC Advances 5: 71942-71954.

31. Fang L, Yang G, Song Y, Lin N (2014) Application of isoabsorption plots generated by high-performance liquid chromatography with diode array detection to the development of multi-component quantitative analysis of traditional herbal medicines. J Sep Sci 37: 3245-3252.

32. Holser RA (2014) Near-infrared analysis of peanut seed skins for catechins. American Journal of Analytical Chemistry 5: 378-383.

33. Banwell NC (1996) Fundamentals of molecular spectroscopy. Tata Mgraw Hill publishing company.

34. Stierle A, Strobel G, Stierle (1993) Taxol and taxane production by Taxomyces andreanae, an endophytic fungus of Pacific yew. Science 260: 214-216.

35. Strobel GA, Hess WM, Ford E, Sidhu RS, Yang X (1996) Taxol from fungal endophytes and issue of biodiversity. J Ind Microbiol 17: 417-423.

36. Kim SU, Strobel GA, Ford E (1999) Screening of taxol-producing endophytic fungi from Ginkgo biloba and Taxus cuspidata in Korea. Agricult Chem Biotechnol 42: 97-99.

37. Tian R, Yang Q, Zhou G, Tan J, Zhang L (2006) Taxonomic study on a taxol producing fungus isolated from bark of Taxus chinensis var. mairei. J Wuhan Bota Res 24: 541-545.

38. Yang X, Guo S, Zhang L, Shao H (2003) Selection of producing podophyllotoxin endophytic fungi from podophyllin plant. Nat Prod Res Dev 15: 419-422.

39. Lu L, He J, Yu X, Li G, Zhang X (2006) Studies on isolation and identification of endophytic fungi strain SC13 from harmaceutical plant Sabina vulgaris Ant. and metabolites. Acta Agriculturae Boreali-occidentalis Sinica 15: 85-89.

40. Cao L, Huang J, Li J (2007) Fermentation conditions of Sinopodophyllum hexandrum endophytic fungus on production of podophyllotoxin. Food Ferment Ind 33: 28-32.

41. Murthi GV, Govil G, Kanekar CR, Virmani YP (1938) Proc Ind Acad Sci 8: 519.

42. Ramaswamy S (1942) Crustal structure of coumarin. Curr Sci 4: 197
43. Lino CS, Taveira ML, Viana GSB, Matos FJA (1997) Analgesic and antiinflammatory activities of Justicia pectoralis Jacq and its constituents: Coumarin and umbeliferone. Phytother Res 11: 211-215.

44. de Moura SR, Costa SS, Jansen JM, Silva CA, Lopes CS, et al. (2002) Bronchodilator activity of Mikania glomerata Sprengel on human bronchi and guinea-pig trachea. J Pharm Pharmacol 54: 249-256

45. Lowe SW, Lin AW (2000) Apoptosis in cancer. Carcinogenesis 21: 485-495.

46. Kroemer G, Galluzzi L, Brenner C (2007) Mitochondrial membrane permeabilization in cell death. Physiol Rev 87: 99-163.

47. Porter AG, Janicke RV (1999) Emerging roles of caspases in apoptosis. Cell Death and Differentiation 6: 99-104

48. Mcllwain DR, Berfest G, Mak TW (2013) Caspase functions in cell death and diseases. Cold Spring Harb Perspect Biol 1-29.

49. Wang J, Chun HJ, Wong W, Spencer DM, Lenardo MJ (2001) Caspase-10 is an initiator caspase in death receptor signaling. Proc Natl Acad Sci USA 98 13884-13888.

50. Ahmed A, Jamil K (2011) Cytotoxicity of neoplastic drugs Gefitinib, Cisplatin 5-FU, Gemcitabine, and Vinorelbine on human cervical cancer cells (HeLa). Biol Med 3: 60-71.

51. Varalakshmi KN, Prerana V, Pal A, Dharod H, Shukla M et al. (2013) A nove metabolite from Aspergillus ochraceus JGI 25 showing cytotoxicity to Hela cells. Indian J Pharm Sci 75: 507-514.

52. Kuriakose GC, Singh S, Rajvanshi PK, Surin WR, Jayabaskaran C (2014) In vitro cytotoxicity and apoptosis induction in human cancer cells by culture extract of an endophytic Fusarium solani strain isolated from Datura metel L. Pharm Anal Acta 5: 4-8.

53. Alvarez-Delgado C Reyes-Chilpa $R$, Estrada-Muniz $E$, Mendoza-Rodriguez CA, Quintero-Ruiz A, et al. (2009) Coumarin A/AA induces apoptosis-like cell death in HeLa cells mediated by the release of apoptosis-inducing factor. $J$ Biochem Mol Toxicol 23: 263-272.

54. Chuang JY, Huang YF, Lu HF, Ho HC, Yang JS, et al (2007) Coumarin induces cell cycle arrest and apoptosis in human cervical cancer HeLa cells through a mitochondria and caspase-3 dependent mechanism and NF-kappaB downregulation. In Vivo 21: 1003-1009. 